\title{
The Effect of Trade Liberalization on Firm Entry and Exit in Punjab, Pakistan
}

\section{Marjan Nasir*}

\begin{abstract}
This study focuses on the impact of trade liberalization on firm entry and exit in Punjab's export manufacturing sector over the decade 2001-10. As far as the province's export industries are concerned, real exchange rate depreciation attracts new firms but also leads weaker firms to exit. A reduction in local or international tariffs, however, has no significant impact on firm entry or exit.
\end{abstract}

Keywords: trade liberalization, exchange rates, firm entry, Pakistan.

JEL classification: F41.

\section{Introduction}

The industrial organization literature has traditionally emphasized the role of new firms as stimulators of economic development. The entry of new firms is associated with employment changes, product and technological innovation, and other structural changes in that particular industry (Roberts \& Thompson, 2003). Furthermore, as incumbent firms face growing competition from the new arrivals, their productivity is expected to improve.

Researchers have examined the relationship between trade liberalization and firm turnover to determine the extent to which international markets and policies influence regional industries and their development. Exchange rate depreciation and tariff reductions can lead to the expansion of exports as the output of existing firms increases or new firms enter the industry (Bernard and Jensen, 2004; Gu, Sawchuk, and Whewell, 2003). Domestic firms can face increased competition from abroad when domestic tariff rates fall or the domestic currency appreciates (Baggs, Beaulieu, \& Fung, 2009; Fung, 2008; Head and Ries, 1999; Klein, Schuh, and Triest, 2000). The primary aim of this study is to analyze the impact of exchange rate depreciation and tariff reductions on the output resulting from the entry of new firms. However, it is pertinent to note that

\footnotetext{
${ }^{*}$ Teaching fellow, Lahore School of Economics, Lahore, Pakistan.
} 
entry into the exports sector requires that firms are at least as productive as the incumbent firms in order to survive both local and foreign competition, which could otherwise lead them to exit if they do not deliver efficiently.

Over the last decade, Pakistan has experienced currency depreciations against the US dollar and the euro, together with an increase in export volume. In 2010, nearly 22 percent and 17 percent of its exports went to the European Union (EU) and the US, respectively; 48 other countries, each receiving a minimal share, accounted for the remaining volume. Accordingly, we look only at those sectors that export to the US and EU, while the depreciating rupee provides an opportunity to study its effects on firm turnover on the export industries in Punjab.

At the same time, the tariff rates of member countries of the World Trade Organization (WTO) have decreased since 2000, in an effort to boost world exports. Pakistan has also experienced this decline together with an increase in exports to the US and EU.

This study looks at the impact of spatial and industrial concentration, currency depreciation, and tariff reductions on the entry and exit rates of manufacturing firms in Punjab. Section 2 provides a literature review, Section 3 gives a theoretical background, and Section 4 describes the data used and descriptive statistics. Section 5 estimates the study's econometric model Section 6 analyzes firm entry, exit and trade liberalization in the context of the results while Section 7 concludes the study.

\section{Literature Review}

The literature on firm entry differentiates between new entrantsalso referred to as greenfield firms-and existing or diversifying firms that have set up plants in different geographical areas and/or expanded their range of products. The importance of studying entry rates is associated positively with regional development. Whether the benefits are direct (in the form of job creation) or indirect (such as improvements in supply conditions), new establishments are known to stimulate economic development. They add to the resource flows of an industry (Roberts \& Thompson, 2003), thus enhancing its productivity and contributing to product and technological innovation. According to Hopenhayn (1992), firms in the manufacturing sector tend to be replaced by new entrants over five-year periods, with a similar trend in job

turnover. However, Fritsch and Mueller (2004) suggest that these benefits can take as long as eight years to occur. 
Earlier studies have looked at the impact of macroeconomic shocks such as large exchange rate movements, changes in export and import duties, or international trade treaties that ease trade between the signatories. The empirical evidence shows that trade liberalization can affect the growth of exports by changing the entry, exit, and production decisions of heterogeneous firms that are major contributors to the economy's export sector. Trade liberalization in this context implies the depreciation or devaluation of the home currency, making home products relatively cheaper in the international market. However, it can also imply a reduction in tariffs by importing countries, which, again, influences the price of the final product sold to trading partners.

A currency appreciation is found to reduce sales and thus affect the survival of existing firms that might otherwise deter the entry of new firms (Baggs, Beaulieu, \& Fung, 2009). However, the impact on firm survival is smaller for more productive firms, either because their technology is superior or their labor force more efficient. Domestic currency appreciation gives foreign firms a cost advantage and forces domestic firms or exporters to reduce their prices as a result of the rise in competition. This fall in price makes it difficult for some firms to maintain their mark-up and, as a result, compels them to exit the industry. On the other hand, currency depreciation tends to increase the number of establishments as well as the scale of production of existing firms (Head \& Ries, 1999).

Klein, Schuh, and Triest (2000) have put forward similar findings on the significant role played by currency appreciation on job destruction. They show that job flows respond asymmetrically to changes in the real exchange rate, i.e., while job destruction is affected by the exchange rate, job creation is not. Moreover, how sensitive job destruction is to exchange rate fluctuations depends on the extent of the industry's exposure to trade. A contributing factor to this analysis is that workers can be laid off immediately once a firm finds it optimal to do so, while hiring new labor often requires screening and training. As a result of these delays, it may be difficult to identify the response of job creation to exchange rate changes, even if the response does exist.

Changes in the exchange rate influence an economy by affecting its exports and imports. Dominguez and Tesar (2006) find that these changes are also correlated with firm and industry characteristics such as firm size, multinational status, international sales, international assets, and competitiveness. A favorable exchange rate movement may result in a boom in the exports market either through an expansion in the output of 
existing producers or through the entry of new firms or both, depending on the barriers to entry that exist for that industry.

Bernard and Wagner (2001) assess firms' decision whether to enter the exports market and conclude that entry entails considerable sunk costs. Firm entry into the exports sector depends on firm size and productivity, which ultimately determines their level of success. Bernard and Jenson (2004) present a similar analysis for the US exports boom from 1987 to 1992. They argue that entry for firms in the exports sector is costly, even if there are favorable shocks in the international market. Using plant-level data, they find that a depreciating exchange rate and rising foreign income increases exports, while the existence of sunk costs increases the contribution of existing - as opposed to new-exporters.

So while exchange rate movements appear to have significant impacts, the evidence for tariff reductions, however, is weak. Head and Ries (1999) find that a decrease in home tariffs increases plant closure and reduces the scale of production of existing plants in the home country. However, a reduction in foreign tariffs increases the scale of production but does not induce the entry of new firms. After adding controls for exchange rate changes and fixed costs in terms of research and development, the authors find no significant change in the tariff coefficient.

$\mathrm{Gu}$, Sawchuk, and Whewell (2003) use a panel dataset comprising 81 manufacturing firms over 14 years to determine the productivity (in the shape of firm size and turnover) caused by a reduction in tariffs under the free trade agreement between the US and Canada. The results suggest that less productive firms will exit after tariffs are reduced, while tariff reductions have no significant impact on the scale of production of existing firms.

In comparison to changes in tariffs, large fluctuations in exchange rates are considered to have greater consequences for firm performance and turnover. Fung (2008) uses data on a Taiwanese firm to study the impact of large fluctuations in the exchange rate on firm performance and turnover. By including an exchange rate variable in the firm's profit function, the study analyzes the impact of an appreciation of the New Taiwan dollar on the scale of production of existing firms and the exit rate in the industry. Intuitively, firm exit will rise as a result of currency appreciation because the costs of domestic firms will increase, forcing less productive firms to shut down. The results indicate that the relationship between currency appreciation and firm scale and productivity depends significantly on the magnitude and direction of changes in output and exports. 
Given the temporary nature of changes in the exchange rate, however, firms are unlikely to change their production activities at all. Baggs et al. (2009) conducted a firm-level analysis of Canadian manufacturing firms for the period 1986 to 1997, incorporating exchange rate data with respect to the US dollar. This timeframe was divided naturally such that, during the first six years, the Canadian dollar appreciated by about 30 percent, after which it depreciated by 30 percent during the next six years. The model regressed three variables, i.e., firm survival, entry, and sales, individually on the trade-weighted exchange rate, the tariff rates of the two countries, and various control factors. The results suggested that the exchange rate had a stronger impact on firm survival, entry, and sales than tariff rates.

\section{Theoretical Background}

The study's theoretical background is based on Krugman's (1979) model, which looks at the effects of trade liberalization on the scale of production and the productivity of firms. Subsequently, Melitz (2003), Fung (2008), and Baggs et al. (2009) have extended this model in their analyses, particularly with the inclusion of an exchange rate variable to incorporate the effects of international trade on domestic industries.

These models assume that labor is the only factor of production and that a domestic currency appreciation gives foreign firms a cost advantage (in terms of the domestic currency). This increases the competition faced by domestic firms in the local and international markets, forcing them to decrease their own prices. The increase in competition and fall in prices charged will lead some firms to exit the industry. Accordingly, currency depreciation has the opposite effect and gives new firms an incentive to enter the industry.

A brief overview of the mathematical specification of the model adopted by Fung (2006) starts with the expenditure function below:

$\ln E(p, u)=\ln u+\sum_{i=1}^{\tilde{n}} \alpha_{i} \ln P_{i}+\frac{1}{2} \sum_{i} \sum_{j} \gamma_{i j} \ln P_{i} \ln P_{j} \quad$ with $\gamma_{i j=} \gamma_{j i}$,

where $\tilde{\mathrm{n}}$ represents the sum of local and foreign varieties and $P$ is the price charged by firm $i$. The demand function derived is represented by $C_{i}=s_{i} E / P_{i}$ where $E$ is total expenditure and $s_{i}$ is the share of expenditure of firm $i$ denoted by:

$$
S_{i}=\frac{P_{i} C_{i}}{E}=\frac{\partial \ln E(P, u)}{\partial \ln P_{i}}=\alpha_{i}+\sum_{j} \gamma_{i j} \ln P_{j}
$$


The use of a symmetric expenditure function in translog form to derive the demand curve leads to varying mark-ups and scales of production for the sample firms. This is different from Krugman's (1979) initial model where the assumption of a constant elasticity of scale meant that the elasticity and scale of production were held constant, i.e., unaffected by exogenous shocks.

We also assume that the expenditure function is homogenous of degree one, thus $\sum_{i} \alpha_{i}=1$ and $\sum \gamma_{i j}=\sum \gamma_{j i}=0$ and that the price elasticity of demand, which is positive, is represented by:

$$
\varepsilon_{i}=1-\frac{\partial \ln s_{i}}{\partial \ln P_{i}}=1-\frac{\gamma_{i i}}{s_{i}}
$$

where $\gamma_{i i}<0$ for demand to be elastic. The assumption of symmetry is imposed on foreign $(f)$ and domestic $(d)$ goods indicated by: $P_{i d}=P_{d}$, $C_{i d}=C_{d}$ and $P_{i f}=P_{f}, C_{i f}=C_{f}$. Given this assumption, the following restrictions are applied:

$$
\alpha_{i}=\frac{1}{\tilde{n}}, \gamma_{i i}=-\frac{\gamma}{\tilde{n}}, \text { and } \gamma_{i j}=\frac{\gamma}{\tilde{n}(\tilde{n}-1)} \quad \text { for } j \neq i, \quad \text { where } \gamma>0
$$

Therefore, the demand elasticities $\left(\varepsilon_{i}\right)$ are:

$$
\begin{aligned}
& \varepsilon_{d}=1+\frac{\gamma}{\tilde{n} s_{d}}=1+\gamma\left[1-\frac{n_{f} \gamma}{(\tilde{n}-1)}\left(\ln P_{d}-\ln P_{f}\right)\right]^{-1} \\
& \varepsilon_{f}=1+\frac{\gamma}{\tilde{n} s_{f}}=1+\gamma\left[1-\frac{n_{d} \gamma}{(\tilde{n}-1)}\left(\ln P_{d}-\ln P_{f}\right)\right]^{-1}
\end{aligned}
$$

Interpreting equation (5) above is necessary as it shows the relationship between the elasticity and price of one good relative to competing goods. The equation indicates a positive relationship, implying that an increase in the price of an imported or foreign good $(f)$ will reduce the competition faced by domestic firms, resulting in a lower elasticity of demand for local firms $\left(\varepsilon_{d}\right)$ and a higher elasticity for foreign firms $\left(\varepsilon_{f}\right)$. This will eventually increase domestic firms' mark-up over cost, and attract other firms to enter the profit-making industry.

On the supply side, given that $n$ is the number of firms producing in a monopolistically competitive industry, the total production of firm $i$ is $\left(X_{i}+X_{i}^{*}\right)$ i.e., the sum of domestic sales and exports. The cost of the only input, labor, is $l_{i}=\alpha+\alpha_{x}+\beta\left(X_{i}+X_{i}^{*}\right)$, where $\alpha$ is the fixed cost, $\alpha_{i}$ is 
the fixed cost of exports, and $\beta$ is the marginal cost. Given this cost information, the profit function of the exporting firm is:

$$
\pi_{i}\left(X_{i}, X_{i}^{*}\right)=P_{i} X_{i}+e P_{i}^{*} X_{i}^{*}-w\left[\alpha+\alpha_{x}+\beta\left(X_{i}+X_{i}^{*}\right)\right]
$$

where $e$ is the exchange rate (the amount of domestic currency per unit of foreign currency), $w$ is the wage level, and $P_{i}^{*}$ is the price in foreign currency of firm $i^{\prime}$ s exports.

In this partial equilibrium model, $n_{d}$, the number of domestic firms, is endogenous, keeping all other factors constant. The equilibrium quantity of domestic sales and exports is:

$$
\begin{aligned}
& X_{i}=X_{d}=C_{d}=s_{d} \frac{w L}{P_{d}}=\frac{\gamma L}{\tilde{n} \varepsilon_{d} \beta} \\
& X_{i}^{*}=X_{d}^{*}=C_{d}^{*}=s_{d}^{*} \frac{W^{*} L^{*}}{P_{d}^{*}}=\frac{\gamma^{*} w^{*} L^{*} e}{\tilde{n} \varepsilon_{d}^{*} \beta w}
\end{aligned}
$$

where $L$ and $L^{*}$ are units of domestic and foreign labor, respectively, with the additional assumptions that $w L=E$ and $w^{*} L^{*}=E^{*}$. Given the above model and related assumptions, we can conclude that, in the case of currency depreciation (increase in $e$ ), domestic firms will have a cost advantage over foreign firms. This will, in turn, increase the number of domestic firms $\left(n_{d}\right)$ as well as total firms $(\tilde{n})$ in the industry. Equation (8) shows that a rise in $e$ leads to an expansion in exports, i.e., an increase in $X^{*}$.

$$
\tilde{n}=\frac{\gamma^{*} e P_{d}^{*}}{\varepsilon_{d}^{*} \beta w s_{d}^{*}}
$$

Equation (9) solves for the number of firms $\tilde{n}$, which establishes that a rise in $e$ (depreciation) results in an increase in the total number of firms in the industry.

\section{Data and Descriptive Statistics}

We have used data from the Directory of Industries (compiled by the Punjab government) for 2002, 2006, and 2010. On average, the directory includes approximately 18,000 manufacturing firms. It also provides the names and addresses of all firms across nearly 180 industries in Punjab. Other information includes the year of establishment, the total number of employees, and each firm's initial investment. Table A1 in the Appendix gives the total number of firms in each industry for 2002 and 2006. In 
almost every industry, the number of firms has either increased or decreased, indicating the variability of firm turnover across sectors.

The employment information provided by the directory is used to calculate the agglomeration index and determine firm size, while initial investment is used as a control factor to proxy for sunk costs.

\subsection{Descriptive Statistics}

Table 1 gives industry and firm descriptive statistics. In 2006, there were 180 industries comprising 18,007 firms operating in Punjab. From 2002 to 2006, the mean firm entry rate was 10 percent while the exit rate was 25 percent. Output growth was high over the five-year period with firms undertaking an initial investment of approximately PRs 40 million on average (with a median value of USD 2,648,000).

Table 1: Descriptive statistics, 2006 (all industries)

\begin{tabular}{lr}
\hline Number of industries & 180 \\
Number of firms & 18,007 \\
Mean firm age & 17 \\
Mean number of employees & 48 \\
Mean industry entry rate & 0.10 \\
Mean industry exit rate & 0.25 \\
Mean industry E-G index (2002) & 0.1554 \\
Mean industry output growth (\%) & 86 \\
Mean initial investment (PRs '000) & 40,892 \\
\hline
\end{tabular}

Source: Government of Punjab, Directory of Industries.

For the trade liberalization analysis, we have used annual exchange rate data from the Federal Bureau of Statistics and data on tariff rates from the WTO. The latter provides tariff averages for its member countries across a large range of goods for multiple years. These were used to calculate tariff changes in order to assess their impact on the entry and exit rates of new firms. The exchange rate data was used to construct a tradeweighted real exchange rate. Our analysis includes 25 industries in Punjab exporting to the US and EU.

Table 2 presents descriptive statistics for the industries exporting to the US and EU. Their average entry and exit rates are higher in the first five-year period than the second five-year period. In the latter half of the 
decade, industrial concentration fell, indicating that export firms faced higher competition from incumbent firms. Tariffs fell between 2001 and 2005, but from 2006 to 2010 the average rate increased for industries exporting to the EU. The trade-weighted real exchange rate appreciated slightly from 2006 to 2010 .

Table 2: Descriptive statistics for export industries

\begin{tabular}{lrr}
\hline & $\mathbf{2 0 0 1 - 0 5}$ & $\mathbf{2 0 0 6} \mathbf{- 1 0}$ \\
\hline Number of export industries & 25 & $\mathbf{2 5}$ \\
Number of firms & 11,620 & 7,600 \\
Mean firm age & 18 & 21 \\
Mean number of employees & 67 & 69 \\
Mean industry entry rate & 0.105 & 0.029 \\
Mean industry exit rate & 0.41 & 0.1 \\
Mean industry concentration (Herfindahl index) & 0.1365 & 0.0628 \\
Mean industry output growth (\%) & 25 & 46 \\
Mean initial investment (PRs '000) & 137,403 & 150,415 \\
Mean tariff change (Pakistan) & -7.187 & 0.164 \\
Mean tariff change (EU) & -0.328 & 0.007 \\
Mean tariff change (US) & -0.596 & -0.131 \\
Mean trade-weighted real exchange rate & 0.012 & 0.0153 \\
\hline
\end{tabular}

Source: Government of Punjab, Directory of Industries.

Table 3 lists the top 20 industries in Punjab in descending order of entry, while Table 4 lists the top 20 industries in descending order of exit. Table 5 shows industry concentration as measured by the E-G index of agglomeration. 
Table 3: Top 20 industries in Punjab with highest entry rates, 2006

\begin{tabular}{llc}
\hline No. & \multicolumn{1}{c}{ Industry } & Entry rate $^{*}$ \\
\hline 1 & Gypsum & 0.93 \\
2 & Mineral water & 0.55 \\
3 & Firefighting equipment & 0.50 \\
4 & Motorcycles/rickshaws & 0.50 \\
5 & Radios/TVs & 0.50 \\
6 & Welding electrodes & 0.50 \\
7 & Zips & 0.50 \\
8 & Knitted textiles & 0.45 \\
9 & Embroidery & 0.43 \\
10 & Cones & 0.43 \\
11 & Yarn doubling & 0.41 \\
12 & Powder coating & 0.33 \\
13 & Pesticides and insecticides & 0.32 \\
14 & Citrus grading & 0.29 \\
15 & Fruit juices & 0.29 \\
16 & Readymade garments & 0.28 \\
17 & Gas appliances & 0.28 \\
18 & Textile made-ups & 0.28 \\
19 & Ceramics & 0.28 \\
20 & Fertilizer & 0.27 \\
\hline
\end{tabular}

* Note: Entry rate in industry $i=$ number of new firms in industry $i$ in 2006 that did not exist in 2002, divided by the total number of firms in industry $i$ in 2006.

Source: Government of Punjab, Directory of Industries. 
Table 4: Top 20 industries in Punjab with highest exit rates, 2006

\begin{tabular}{|c|c|c|}
\hline No. & Industry & Exit rate \\
\hline 1 & Bus bodies & 0.99 \\
\hline 2 & Nuts and bolts & 0.97 \\
\hline 3 & Spices & 0.95 \\
\hline 4 & Electroplating & 0.89 \\
\hline 5 & Electric furnaces & 0.88 \\
\hline 6 & Bakery products & 0.85 \\
\hline 7 & Photographic goods & 0.83 \\
\hline 8 & Razors/safety razors/blades & 0.83 \\
\hline 9 & Dyes and blocks & 0.80 \\
\hline 10 & Knitted textiles & 0.79 \\
\hline 11 & Ice cream & 0.79 \\
\hline 12 & Zinc sulfate & 0.75 \\
\hline 13 & Bicycles & 0.75 \\
\hline 14 & Hand-powered tools & 0.67 \\
\hline 15 & Bulbs and tubes & 0.67 \\
\hline 16 & Refineries & 0.67 \\
\hline 17 & Unani medicines & 0.67 \\
\hline 18 & Weights and scales & 0.66 \\
\hline 19 & Agricultural implements & 0.64 \\
\hline 20 & Pins/clips & 0.60 \\
\hline
\end{tabular}

* Note: Exit rate in industry $i=$ number of firms in industry $i$ in 2002 that did not exist in 2006, divided by the total number of firms in industry $i$ in 2002.

Source: Government of Punjab, Directory of Industries. 
Table 5: Top 20 most agglomerated industries in Punjab, 2006

\begin{tabular}{|c|c|c|}
\hline No. & Industry & E-G index* \\
\hline 1 & Electroplating & 1.5948 \\
\hline 2 & Citrus grading & 1.1967 \\
\hline 3 & Wool scouring & 1.1652 \\
\hline 4 & Powder coating & 1.1072 \\
\hline 5 & Musical instruments & 1.0586 \\
\hline 6 & Weights and scales & 1.0529 \\
\hline 7 & Sports goods & 1.0333 \\
\hline 8 & Leather garments & 0.9820 \\
\hline 9 & Surgical instruments & 0.9380 \\
\hline 10 & Utensils (all sorts) & 0.9254 \\
\hline 11 & Belts & 0.9214 \\
\hline 12 & Canvas shoes & 0.8583 \\
\hline 13 & Raising cloth & 0.8529 \\
\hline 14 & Cutlery & 0.8209 \\
\hline 15 & Fiber tops & 0.8169 \\
\hline 16 & Polyester yarn & 0.8091 \\
\hline 17 & Crown corks & 0.7284 \\
\hline 18 & Fiberglass & 0.7151 \\
\hline 19 & Sanitary fittings & 0.7131 \\
\hline 20 & Machine tools & 0.7128 \\
\hline
\end{tabular}

* Note: E-G index in 2002 measured using employment data.

Source: Government of Punjab, Directory of Industries.

\section{Econometric Model and Estimation Technique}

We have designed two separate models to determine the impact of agglomeration and trade liberalization on firm entry and exit, controlling for industry-level factors. Table 6 defines all the variables used. 
Table 6: Variable names and definitions

\begin{tabular}{|c|c|}
\hline Explanatory variable & Definition \\
\hline E-G index & $\begin{array}{l}\text { Constructed using firm employment; consists of the } \\
\text { Gini coefficient and Herfindahl index. }\end{array}$ \\
\hline ER & $\begin{array}{l}\text { Trade-weighted real exchange rate with respect to the } \\
\text { USD and EUR (increase = appreciation of PRe) }\end{array}$ \\
\hline$\Delta$ tariff ${ }^{P K}$ & Change in tariff rates in Pakistan from 2001 to 2010 \\
\hline$\Delta$ tariff $f_{S}$ & Change in tariff rates in the US from 2001 to 2010 \\
\hline$\Delta$ tariff ${ }^{E U}$ & Change in tariff rates in the EU from 2001 to 2010 \\
\hline Average firm age & Average age of a firm in an industry (since establishment) \\
\hline Average firm size & $\begin{array}{l}\text { Average size of a firm in an industry as measured by } \\
\text { its number of employees }\end{array}$ \\
\hline Output growth & Change in output during the time period \\
\hline Sunk cost & Average initial investment of firms in an industry \\
\hline Industry concentration & Herfindahl index measured using employment data \\
\hline
\end{tabular}

The model for trade liberalization draws on Baggs et al. (2009), where the entry and exit of firms is regressed on the real exchange rates of Pakistan's two major trading partners, the US and the EU, together with the tariff rates of the three regions under analysis. The model specification is given below:

$$
\begin{aligned}
\text { Entry }_{i t}= & E_{i t}=\frac{N_{i t}}{I_{i t}}=\beta_{0}+\beta_{1} E R_{i t}+\beta_{2} \Delta \text { tariff } f_{i t}^{P K}+\beta_{3} \Delta \text { tariff } f_{i t}^{U S}+ \\
& \beta_{4} \Delta \text { tariff } f_{i t}^{E U}+\beta_{5} X_{i t}+\tau_{t}+I_{i}+\varepsilon_{i t}
\end{aligned}
$$

where $E_{i t}$ is the number of new firms in industry $i$ in year $t\left(N_{i t}\right)$ divided by the total number of firms in industry $i$ in year $t\left(I_{i t}\right) . E R_{i t}$ is the industry-specific trade-weighted real exchange rate. $\Delta$ tariff $_{i t}$ is the change in Pakistan, US, and EU tariff rates at the industry level. $X$ is a vector of control factors (firm age, firm size, sunk costs, output growth, and concentration index). $\tau_{t}$ represents time fixed effects and $I_{i}$ industry fixed effects.

The variable measuring entry is measured for 25 export industries and two periods, i.e., $t=1$ (2002 to 2005) and $t=2$ (2006 to 2010). The year of establishment is used to indicate that a firm is a new entrant. Thus, the entry rate of industry $i$ in year $t$ is the number of entrants in $t$ as a fraction of the total number of firms in that industry for that period. 


$$
\begin{gathered}
\text { Exit }_{i t}=Z_{i t}=\frac{M_{i t}}{F_{i t}}=\beta_{0}+\beta_{1} E R_{i t}+\beta_{2} \Delta \text { tariff }_{i t}^{P K}+\beta_{3} \Delta \text { tariff }_{i t}^{U S}+ \\
\beta_{4} \Delta \text { tariff } f_{i t}^{E U}+\beta_{5} X_{i t}+\tau_{t}+I_{i}+\varepsilon_{i t}
\end{gathered}
$$

$Z_{i t}$ is the exit rate in industry $i$ and equals the number of firms in industry $i$ in year $t$ that did not exist in $t+1\left(M_{i}\right)$ divided by the total number of firms in industry $i$ in year $t\left(F_{i}\right) . E R_{i t}$ is the industry-specific trade-weighted real exchange rate. $\Delta$ tariff $_{i t}$ is the change in Pakistan, US, and EU tariff rates at the industry level. $X$ is a vector of control factors (firm age, firm size, sunk costs, output growth, and concentration index). $\tau$ represents time fixed effects and $I_{i}$ are industry fixed effects.

The exit variable is also measured for two periods, i.e., $t=1$ and $t=$ 2. The number of firms that were present in year $t$ but not in $t+1$ as a fraction of the total number of firms in industry $i$ in year $t$ gives us the exit rate. The trade-weighted real exchange rate variable (see Baggs et al., 2009, appendix) $(E R)$ is constructed using the equation

$$
\text { ExchangeRate }_{i t}=E R_{i t}=\sum_{j \in t o p 2} T W_{i j} r e r_{j t}
$$

where $i$ represents industry, $j$ represents the top two trading partners of the industry (the US and EU in the case of Pakistan), and $t$ represents the time period. $T W_{i j}$ or the trade weight is estimated by taking the share of the industry's exports and imports with its trading partners as a proportion of the total exports and imports of all the manufacturing industries exposed to trade with the top two trading countries. The equation for the trade weight is shown below:

$$
T W_{i j}=\frac{(X+M)_{i j}}{\sum_{j \in t o p 2_{i}} \sum(X+M)_{i j}}
$$

where $(X+M)$ is the sum of exports and imports for the two periods. The term rer $_{j t}$ refers to the real exchange rate in terms of the two trading countries, which is normalized for each country using 2000 as the base year. ${ }^{1}$

The WTO tariff rates for 2002 and 2010 for the 25 export industries in our analysis are used to construct the variable $\Delta$ tariff ${ }_{i t}$, which can be expressed as follows:

\footnotetext{
${ }^{1}$ This is done to avoid the unit problem, which occurs when bilateral exchange rates have different units.
} 


$$
\begin{aligned}
& \Delta \text { tariff }_{i 1}=\text { tariff }_{i 2006}-\text { tariff }_{i 2002} \text { for } t=1 \\
& \Delta \text { tariff }_{i 2}=\text { tariff }_{i 2010}-\text { tariff }_{i 2006} \text { for } t=2
\end{aligned}
$$

where tariff $_{i}$ is the simple average rate for the different product categories provided by the WTO. It is also necessary to control for other factors that affect the entry and exit of firms in order to minimize omitted variable bias. Initial investment is used as a proxy for sunk costs. Other control variables include industry concentration (Herfindahl index), average firm size, age, and output growth in the industry.

We use ordinary least squares to estimate the models while accounting for time and industry fixed effects. Time fixed effects are observed to account for time-variant factors such as government policies. Similarly, industry fixed effects take into account the individual differences between industries, e.g., the nature of the product being produced.

\section{Analysis of Estimates}

The results of the regression analysis indicate that an appreciation of the trade-weighted real exchange rate lowers the rate of exit of existing firms and the rate of entry of new firms, while depreciation increases the rate of entry as well as rate of exit (see Table 7). Movements in the exchange rate force firms to adjust to new competitive conditions, affecting their entry and exit positions. Currency depreciation makes exports cheaper than imports, thus boosting the sales of export firms. Since these industries enjoy higher rents, they become attractive to potential exporters. The entry of new firms starts to take place, raising the level of competition. This, in turn, causes weaker firms to exit the industry. 
Table 7: Entry and exit/trade liberalization regression results

\begin{tabular}{|c|c|c|c|c|}
\hline & \multicolumn{2}{|c|}{ Entry } & \multicolumn{2}{|c|}{ Exit } \\
\hline & (1) & (2) & (3) & (4) \\
\hline $\begin{array}{l}\text { ER } \\
\text { (Increase }=\text { appreciation of PRe) }\end{array}$ & $\begin{aligned}-8.335^{* *} \\
(3.418)\end{aligned}$ & $\begin{array}{l}-7.700 \\
(7.047)\end{array}$ & $\begin{aligned}-31.568^{* *} \\
(12.568)\end{aligned}$ & $\begin{aligned}-61.991^{* *} \\
(27.692)\end{aligned}$ \\
\hline Tariff PK & $\begin{array}{r}-0.0001 \\
(0.002)\end{array}$ & $\begin{array}{r}0.001 \\
(0.003)\end{array}$ & $\begin{array}{r}-0.011 \\
(0.022)\end{array}$ & $\begin{array}{l}-0.015 \\
(0.027)\end{array}$ \\
\hline Tariff EU & $\begin{array}{r}-0.011 \\
(0.014)\end{array}$ & $\begin{array}{r}-0.033 \\
(0.020)\end{array}$ & $\begin{array}{r}0.194 \\
(0.123)\end{array}$ & $\begin{array}{r}0.283^{*} \\
(0.145)\end{array}$ \\
\hline Tariff US & $\begin{array}{r}-0.001 \\
(0.001)\end{array}$ & $\begin{array}{l}-0.001 \\
(0.002)\end{array}$ & $\begin{array}{r}0.004 \\
(0.006)\end{array}$ & $\begin{array}{r}0.018 \\
(0.012)\end{array}$ \\
\hline Concentration index & $\begin{array}{r}-0.067^{* * *} \\
(0.023)\end{array}$ & $\begin{array}{r}-0.013 \\
(0.063)\end{array}$ & $\begin{array}{r}0.202 \\
(0.246)\end{array}$ & $\begin{array}{r}0.261 \\
(0.430)\end{array}$ \\
\hline Output growth & $\begin{array}{r}0.008 \\
(0.014)\end{array}$ & $\begin{array}{r}-0.013 \\
(0.030)\end{array}$ & $\begin{array}{l}0.086^{* *} \\
(0.040)\end{array}$ & $\begin{array}{r}0.142^{*} \\
(0.074)\end{array}$ \\
\hline Firm age & $\begin{array}{r}-0.003 \\
(0.002)\end{array}$ & $\begin{array}{r}-0.004 \\
(0.005)\end{array}$ & $\begin{array}{r}-0.004 \\
(0.006)\end{array}$ & $\begin{array}{r}0.002 \\
(0.014)\end{array}$ \\
\hline $\begin{array}{l}\text { Firm size (small; dummy }=1 \text { if }< \\
49 \text { employees) }\end{array}$ & $\begin{array}{r}-0.060 \\
(0.044)\end{array}$ & $\begin{array}{r}-0.176^{* * *} \\
(0.032)\end{array}$ & $\begin{array}{r}0.209 \\
(0.161)\end{array}$ & $\begin{array}{r}0.655^{* * *} \\
(0.192)\end{array}$ \\
\hline $\begin{array}{l}\text { Firm size (medium; dummy }=1 \\
\text { if } \geq 49 \text { and }<100 \text { employees) }\end{array}$ & $\begin{array}{r}-0.010 \\
(0.045)\end{array}$ & $\begin{array}{r}-0.167^{* * *} \\
(0.037)\end{array}$ & $\begin{array}{c}0.227^{*} \\
(0.130)\end{array}$ & $\begin{array}{r}0.575^{* * *} \\
(0.177)\end{array}$ \\
\hline $\begin{array}{l}\text { Firm size (large; dummy }=1 \text { if } \geq \\
100 \text { employees) }\end{array}$ & - & - & - & - \\
\hline $\begin{array}{l}\text { High cost } \\
\text { (Dummy }=1 \text { if sunk cost }>\text { PRs } \\
50 \mathrm{mn})\end{array}$ & $\begin{array}{l}-0.019 \\
(0.031)\end{array}$ & $\begin{array}{r}-0.157^{* * *} \\
(0.052)\end{array}$ & $\begin{array}{r}0.025 \\
(0.130)\end{array}$ & $\begin{array}{r}-0.455^{* *} \\
(0.214)\end{array}$ \\
\hline Cons. & $0.269^{* * *}$ & $0.456^{*}$ & $0.513^{* * *}$ & $0.583^{*}$ \\
\hline Time and industry fixed effects & NO & YES & NO & YES \\
\hline & $\mathrm{N}=48$ & $\mathrm{~N}=48$ & $\mathrm{~N}=48$ & $\mathrm{~N}=48$ \\
\hline & $\mathrm{R} 2=0.38$ & $\mathrm{R} 2=0.15$ & $\mathrm{R} 2=0.12$ & $\mathrm{R} 2=0.05$ \\
\hline
\end{tabular}

Note: ${ }^{* * *}=$ statistical significance at 1 percent level, ${ }^{* *}=$ statistical significance at 5 percent level, and ${ }^{*}=$ statistical significance at 10 percent level. Robust standard errors are given in parentheses.

Source: Author's calculations.

In terms of magnitude, the results show that an appreciation or depreciation of the trade-weighted real exchange rate seems to affect firm exit more than firm entry. The extent to which each industry is influenced by exchange rate fluctuations depends on its exposure to the export market. Greater exposure puts the firms in that industry at a higher risk of mortality, specifically if they do not have a competitive edge over foreign firms. Baggs et al. (2009), Fung (2008), and Head and Ries (1999) establish 
similar results for the US, Canada, and Taiwan: currency depreciation attracts entry or increases the scale of production, while the appreciation of the home currency deters the entry of new firms.

Gu et al. (2003) and Head and Ries (1999) show that a reduction in foreign rates in bilateral trade increases the rate of exit but has no significant impact on firms' entry or scale of production. On the other hand, a reduction in domestic rates leads to an increase in plant closure and a fall in the scale of production of existing plants in the home country. For Punjab's export industries-apart from the EU tariff variable, which only affects exit at a low significance level-neither of the other two tariff variables seem to have any significant impact on either entry or exit. This could be attributed to the low variation in the tariff rates, with small reductions observed from 2002 to 2006 and even smaller increases from 2006 to 2010.

The coefficient of industrial concentration (Herfindahl index) is negative and significant in our estimation for firm entry without fixed effects in place, indicating that new firms will avoid industries where the market share is concentrated in the hands of a few firms. However, the variable becomes insignificant once fixed effects are incorporated. Also, it has no significant impact on firm exit.

Industrial output growth varies positively with exit rates, again reinforcing the notion that competitive conditions influence firm turnover, specifically causing weaker firms to exit. Additionally, firm entry is lower and firm exit is higher in industries that comprise more small or medium firms, holding other factors constant. This depends on the competitiveness of the firms in that industry. Finally, firms avoid industries that require large sunk or irrecoverable costs; exit rates are also observed to be lower in such industries. Sunk costs are considered a barrier to entry and exit as new firms find it more difficult to raise large amounts. Existing firms that have already undertaken such high initial investment continue operating till they are at least able to cover these costs.

An important conclusion to draw from this analysis is that firm entry $\left(E_{i t}\right)$ and exit $\left(Z_{i t}\right)$ are positively affected by a depreciating real exchange rate $\left(E R_{i t}\right)$, while the tariff reduction and firm turnover relationship remains inconclusive. 


\section{Conclusion}

This study has shown that a real exchange rate appreciation or depreciation is more likely to influence firm entry and exit than large tariff changes. Whether these changes in tariff rates take place in the domestic market or foreign market, they seem to have very little impact on firm turnover. Firm entry is lower and firm exit higher in industries comprising more smaller or medium firms, suggesting that they are more competitive and may pose a threat to new as well as existing firms. Finally, the results highlight the significant role of high initial investment in deterring firm entry and exit. 


\section{References}

Baggs, J., Beaulieu, E., \& Fung, L. (2009). Firm survival, performance, and the exchange rate. Canadian Journal of Economics, 42(2), 393-421.

Bernard, A. B., \& Jenson, J. B. (2004). Entry, expansion, and intensity in the US export boom, 1987-1992. Review of International Economics, 12(4), 662-675.

Bernard, A. B., \& Wagner, J. (2001). Export entry and exit by German firms. Review of World Economics (Weltwirtschaftliches Archiv), 137(1), 105-123.

Carlton, D. W. (1983). The location and employment choices of new firms: An econometric model with discrete and continuous endogenous variables. Review of Economics and Statistics, 65(3), 440-449.

Caves, R. E. (1998). Industrial organization and new findings on the turnover and mobility of firms. Journal of Economic Literature, 36(4), 1947-1982.

Dominguez, K. M. E., \& Tesar, L. L. (2006). Exchange rate exposure. Journal of International Economics, 68(1), 188-218.

Fajnzylber, P., Maloney, W. F., \& Ribeiro, E. (2001). Firm entry and exit, labor demand, and trade reform: Evidence from Chile and Colombia (Policy Research Working Paper No. 2659). Washington, DC: World Bank.

Fritsch, M., \& Mueller, P. (2004). The effects of new business formation on regional development over time. Regional Studies, 38(8), 961-976.

Fung, L. (2008). Large real exchange rate movements, firm dynamics, and productivity growth. Canadian Journal of Economics, 41(2), 391-424.

Geroski, P. A. (1995). What do we know about entry? International Journal of Industrial Organization, 13(4), 421-440.

Gu, W., Sawchuk, G., \& Whewell, L. (2003). The effect of tariff reductions on firm size and firm turnover in Canadian manufacturing. Review of World Economics (Weltwirtschaftliches Archiv), 139(3), 440-459. 
Head, K., \& Ries, J. (1999). Rationalization effects of tariff reductions. Journal of International Economics, 47(2), 295-320.

Hopenhayn, H. A. (1992). Entry, exit, and firm dynamics in long-run equilibrium. Econometrica, 60(5), 1127-1150.

Klein, M. W., Schuh, S., \& Triest, R. K. (2000). Job creation, job destruction and the real exchange rate (Working Paper No. 7466). Cambridge, MA: National Bureau of Economic Research.

Krugman, P. R. (1979). Increasing returns, monopolistic competition, and international trade. Journal of International Economics, 9(4), 469-479.

Melitz, M. J. (2003). The impact of trade on intra-industry reallocations and aggregate industry productivity. Econometrica, 71(6), 16951725.

Roberts, B. M., \& Thompson, S. (2003). Entry and exit in a transition economy: The case of Poland. Review of Industrial Organization, 22(3), 225-243.

Soubeyran, A., \& Thisse, J. F. (1998). Learning-by-doing and the development of industrial districts. Journal of Urban Economics, 45(1), 156-176. 


\section{Appendix}

Table A1: Number of firms in Punjab's manufacturing sector, 2002 and 2006

\begin{tabular}{|c|c|c|c|c|c|c|c|}
\hline & Industry & 2002 & 2006 & & Industry & 2002 & 2006 \\
\hline 1 & $\begin{array}{l}\text { Air conditioners/ } \\
\text { refrigerators / } \\
\text { deep-freezers }\end{array}$ & 10 & 15 & 91 & $\begin{array}{l}\text { Liquified petroleum } \\
\text { gas (LPG) }\end{array}$ & 0 & 6 \\
\hline 2 & $\begin{array}{l}\text { Agricultural } \\
\text { implements }\end{array}$ & 751 & 419 & 92 & Lubricants & 21 & 10 \\
\hline 3 & Aluminum products & 16 & 35 & 93 & Machine tools & 65 & 62 \\
\hline 4 & $\begin{array}{l}\text { Arms and } \\
\text { ammunition }\end{array}$ & 12 & 9 & 94 & Marble & 222 & 6 \\
\hline 5 & Automobile parts & 287 & 278 & 95 & Matches & 2 & 2 \\
\hline 6 & Bakery products & 164 & 35 & 96 & $\begin{array}{l}\text { Melamine (plastic) } \\
\text { utensils }\end{array}$ & 76 & 65 \\
\hline 7 & Baby bicycles & 5 & 3 & 97 & Mineral water & 0 & 11 \\
\hline 8 & Batteries & 3 & 5 & 98 & Motorcars & 1 & 1 \\
\hline 9 & Belts & 8 & 7 & 99 & $\begin{array}{l}\text { Motorcycles/ } \\
\text { rickshaws }\end{array}$ & 2 & 23 \\
\hline 10 & Beverages & 20 & 22 & 100 & Motors/pumps & 193 & 170 \\
\hline 11 & Bicycles & 102 & 40 & 101 & Musical instruments & 9 & 11 \\
\hline 12 & Biscuits & 29 & 32 & 102 & Nuts and bolts & 216 & 112 \\
\hline 13 & Boilers & 2 & 4 & 103 & Oil stoves & 2 & 1 \\
\hline 14 & Bulbs and tubes & 3 & 3 & 104 & Packages & 93 & 187 \\
\hline 15 & Canvas shoes & 1 & 1 & 105 & Paints and varnishes & 61 & 61 \\
\hline 16 & Carpets & 67 & 50 & 106 & $\begin{array}{l}\text { Paper and paper } \\
\text { board }\end{array}$ & 83 & 110 \\
\hline 17 & Caustic soda & 3 & 1 & 107 & Paper cones & 3 & 22 \\
\hline 18 & Cement & 212 & 43 & 108 & Parachute bags & 1 & 1 \\
\hline 19 & Ceramics & 23 & 111 & 109 & $\begin{array}{l}\text { Pencils/ } \\
\text { ballpoint pens }\end{array}$ & 4 & 6 \\
\hline 20 & Chalk & 1 & 1 & 110 & $\begin{array}{l}\text { Pesticides and } \\
\text { insecticides }\end{array}$ & 12 & 25 \\
\hline 21 & Chemicals & 41 & 85 & 111 & Petroleum products & 0 & 3 \\
\hline 22 & Chip/straw board & 13 & 88 & 112 & Photographic goods & 6 & 1 \\
\hline 23 & Citrus grading & 4 & 41 & 113 & Pins and clips & 5 & 2 \\
\hline 24 & Cold storage & 442 & 633 & 114 & Plaster of Paris & 0 & 1 \\
\hline 25 & Cones & 23 & 7 & 115 & Plastic products & 343 & 287 \\
\hline
\end{tabular}




\begin{tabular}{|c|c|c|c|c|c|c|c|}
\hline & Industry & 2002 & 2006 & & Industry & 2002 & 2006 \\
\hline 26 & Confectionery & 69 & 89 & 116 & Polypropylene bags & 33 & 45 \\
\hline 27 & Cosmetics & 5 & 7 & 117 & Polyester yarn & 4 & 9 \\
\hline 28 & $\begin{array}{l}\text { Cotton ginning and } \\
\text { pressing }\end{array}$ & 1236 & 1358 & 118 & Polythene bags & 12 & 27 \\
\hline 29 & Cotton tape & 2 & 1 & 119 & Pottery & 143 & 185 \\
\hline 30 & Cotton waste & 66 & 56 & 120 & Poultry feed & 85 & 79 \\
\hline 31 & Crown corks & 2 & 2 & 121 & Powder coating & 2 & 3 \\
\hline 32 & Cutlery & 214 & 227 & 122 & Power generation & 43 & 46 \\
\hline 33 & Cycle tyres/tubes & 17 & 21 & 123 & PVC pipes & 30 & 40 \\
\hline 34 & Dairy products & 17 & 25 & 124 & Radios/televisions & 2 & 2 \\
\hline 35 & Diapers (baby) & 2 & 1 & 125 & Cloth raising & 13 & 7 \\
\hline 36 & Dyes and blocks & 94 & 18 & 126 & Razors/blades & 6 & 1 \\
\hline 37 & Diesel engines & 62 & 70 & 127 & Readymade garments & 105 & 364 \\
\hline 38 & Domestic hardware & 107 & 70 & 128 & Refineries & 3 & 2 \\
\hline 39 & Yarn doubling & 16 & 39 & 129 & Rice mills & 1066 & 1717 \\
\hline 40 & $\begin{array}{l}\text { Drugs and } \\
\text { pharmaceuticals }\end{array}$ & 114 & 151 & 130 & Rubber products & 67 & 64 \\
\hline 41 & Dyes & 3 & 3 & 131 & Sanitary fittings & 218 & 252 \\
\hline 42 & Elastic & 0 & 6 & 132 & Seed processing & 8 & 11 \\
\hline 43 & Electric furnaces & 51 & 15 & 133 & $\begin{array}{l}\text { Sewing machines } \\
\text { /parts }\end{array}$ & 25 & 23 \\
\hline 44 & Electric goods & 223 & 219 & 134 & Shoe lasts & 1 & 1 \\
\hline 45 & Electric meters & 5 & 7 & 135 & Yarn sizing & 197 & 204 \\
\hline 46 & Electric poles & 1 & 1 & 136 & Soaps and detergents & 412 & 188 \\
\hline 47 & Electric transformers & 16 & 18 & 137 & Sodium silicate & 42 & 39 \\
\hline 48 & Electroplating & 17 & 1 & 138 & Solvent oil extraction & 18 & 24 \\
\hline 49 & Embroidery & 50 & 150 & 139 & Specialized textiles & 0 & 1 \\
\hline 50 & Essences & 1 & 1 & 140 & Spices & 1 & 2 \\
\hline 51 & Explosives & 1 & 1 & 141 & Sports goods & 500 & 564 \\
\hline 52 & Fans/coolers & 510 & 536 & 142 & Spray machines & 2 & 2 \\
\hline 53 & Fertilizer & 7 & 11 & 143 & Springs & 2 & 1 \\
\hline 54 & Fiberglass & 5 & 6 & 144 & Starch and products & 5 & 4 \\
\hline 55 & Fiber tops & 2 & 2 & 145 & Sugar & 39 & 41 \\
\hline 56 & Fire clay & 1 & 1 & 146 & Sulphuric acid & 10 & 7 \\
\hline 57 & $\begin{array}{l}\text { Fire-fighting } \\
\text { equipment }\end{array}$ & 1 & 2 & 147 & $\begin{array}{l}\text { Surgical cotton/ } \\
\text { bandages }\end{array}$ & 13 & 50 \\
\hline 58 & Flour mills & 437 & 543 & 148 & Surgical instruments & 999 & 1298 \\
\hline 59 & Foam & 8 & 6 & 149 & Synthetic fiber & 0 & 1 \\
\hline
\end{tabular}




\begin{tabular}{|c|c|c|c|c|c|c|c|}
\hline & Industry & 2002 & 2006 & & Industry & 2002 & 2006 \\
\hline 60 & Food products & 39 & 47 & 150 & Synthetic resins & 4 & 5 \\
\hline 61 & Forging & 3 & 17 & 151 & Syringes & 3 & 4 \\
\hline 62 & Foundry products & 762 & 600 & 152 & Tanneries & 524 & 623 \\
\hline 63 & Fruit juices & 22 & 28 & 153 & Tents & 12 & 26 \\
\hline 64 & Fruit preservation & 2 & 1 & 154 & Textile composite & 23 & 28 \\
\hline 65 & GI/MS pipes & 45 & 66 & 155 & Textile made-ups & 32 & 43 \\
\hline 66 & Gas appliances & 29 & 45 & 156 & Textile processing & 355 & 483 \\
\hline 67 & $\begin{array}{l}\text { Glass and glass } \\
\text { products }\end{array}$ & 29 & 42 & 157 & Textile spinning & 309 & 421 \\
\hline 68 & Glue & 5 & 8 & 158 & Textile weaving & 188 & 219 \\
\hline 69 & Glycerin & 1 & 1 & 159 & Thermopore & 6 & 8 \\
\hline 70 & Grinding wheels & 1 & 1 & 160 & Thread & 11 & 9 \\
\hline 71 & Gypsum & 14 & 1 & 161 & Tobacco & 3 & 5 \\
\hline 72 & Handheld tools & 46 & 15 & 162 & Towel & 10 & 17 \\
\hline 73 & Hatcheries & 23 & 21 & 163 & Tractors and parts & 158 & 158 \\
\hline 74 & $\begin{array}{l}\text { Heavy engineering } \\
\text { (bulldozers/cranes, } \\
\text { etc.) }\end{array}$ & 1 & 1 & 164 & Trucks & 1 & 1 \\
\hline 75 & $\begin{array}{l}\text { Homeopathic } \\
\text { medicines }\end{array}$ & 2 & 2 & 165 & Tyres and tubes & 12 & 11 \\
\hline 76 & Hosepipes & 1 & 1 & 166 & Unani medicines & 45 & 18 \\
\hline 77 & Hosiery & 444 & 366 & 167 & Utensils (all sorts) & 534 & 488 \\
\hline 78 & Ice cream & 14 & 11 & 168 & Ghee and cooking oil & 96 & 92 \\
\hline 79 & $\begin{array}{l}\text { Industrial/burn } \\
\text { gases }\end{array}$ & 32 & 28 & 169 & Velvet cloth & 1 & 1 \\
\hline 80 & $\begin{array}{l}\text { Industrial (textile) } \\
\text { machinery }\end{array}$ & 92 & 92 & 170 & Vermicelli & 5 & 10 \\
\hline 81 & Ink & 6 & 6 & 171 & Washing machines & 94 & 105 \\
\hline 82 & $\begin{array}{l}\text { Iron and steel } \\
\text { rerolling }\end{array}$ & 317 & 385 & 172 & Weights and scales & 41 & 14 \\
\hline 83 & Jute mills & 13 & 22 & 173 & Welding electrodes & 2 & 2 \\
\hline 84 & Knitted textiles & 95 & 91 & 174 & Wire and cable & 39 & 77 \\
\hline 85 & Leather footwear & 96 & 100 & 175 & Wooden products & 6 & 6 \\
\hline 86 & Leather garments & 201 & 392 & 176 & Wool scouring & 3 & 4 \\
\hline 87 & Leather products & 51 & 64 & 177 & Woolen textiles & 125 & 132 \\
\hline 88 & Light engineering & 198 & 233 & 178 & Zinc sulphate & 4 & 1 \\
\hline 89 & Locks and padlocks & 32 & 27 & 179 & Zari work & 3 & 3 \\
\hline 90 & LPG (gas) cylinders & 7 & 9 & 180 & Zips & 0 & 1 \\
\hline
\end{tabular}

Source: Government of Punjab, Directory of Industries. 